\title{
Obstacles of Implementing Total Quality Management in Higher Education Institutions: Academic Staff' perspective
}

\author{
Hanaa E. Sabra ${ }^{1}$, Omima M. Abd El zaher ${ }^{2}$ \& Soad S. Mohamed ${ }^{3}$. \\ 1. Assis. Prof. Nursing Administration, Lecturer of Community Health Nursing, Faculty of Nursing, South \\ Valley Univerzity, Quena, Egypt. \\ 2. Assis. Prof. Nursing Administration, Lecturer of Community Health Nursing, Faculty of Nursing, South \\ Valley Univerzity, Quena, Egypt. \\ ${ }^{3 .}$ Lecturer of Psychology, Faculty of art, South Valley University, Quena, Egypt.
}

\begin{abstract}
Total quality management (TQM) in higher education is a new management philosophy that leads universities based on the needs of students and the surrounding community. Aim: To identify obstacles of implementing TQM in higher education institutions from academic staff perspective. Design: A descriptive explorative research design was used. Setting: This study was conducted in Nursing, Engineering, Arts and commerce Faculties at South Valley University (SVU). Subjects: Random sample of (160) academic staff was included. Tools: Self-administrated questionnaire was used for data collection. Results: It showed that the high mean score of TQM application obstacles was related to financial resources, while low mean score was related to top management $(\mathbf{2 0 . 4 4 \pm 3 . 7 5 3 m}$ 17.54 \pm 4.713) respectively. There were statistically significant differences between TQM application obstacles and personal characteristics of participants and between obstacles and application of TQM. Conclusion: The application of TQM in higher education institutions will only be accomplished by providing of supportive infrastructure for change and development of qualified human resources, material, technical infrastructures and update resources for education and learning and all educational institutions and its components should have a genuine desire to work and implement the standards that can represent a permanent plan. Recommendations: Policy maker at SVU must use strategic long term planning and effective policy for services quality; provide training courses and workshops in the field of TQM application.
\end{abstract}

\section{Keywords: Total Quality Management Obstacles, Academic Staff \& Higher Education.}

\section{Introduction}

The higher education in its various dimensions of knowledge, technology and research is essential for developed and developing countries equally, according to the developed ones is to maintain its leadership, and for developing countries to get along with developed countries, hence, the higher education institutions play an important role in construction a good leader, and an important tool to attain progress and development through roles such as teaching, scientific research, and community service. To achieve these roles effectively, the institutions of higher education must be with high quality (Jaafari, 2011 \& Papanthymou. \& Papanthymou, (2017). The higher education recently has witnessed a significant expansion accompanied by an increase in the number of students and academic staff members, but it is noted that this expansion has not been matched with an improvement in the quality of education, even though the education of both types public and higher was still the main progress of any nation (Sahney, Karunes \& Banwet, 2011 \& Bin tareaf, 2013).

The aim of TQM is to utilize resources effectively, to achieve success, imperative to beneficialize the society and all the employees of an organization and to ensure financial stability. Successful TQM implementation results in improving overall organizational performance such as improved employees participation, better communication and improved enrolment of learners, better quality and improved competitive advantage (Karani \& Okibo, 2012 \& Wani \& Mehraj, 2014).

Some institutions may succeed in TQM application programs while others fail. The main reason for failure is the application process. The major obstacles to TQM application are: shortage of clear cultural values, and leadership's commitment to implement TQM, the dominance of authoritarian management styles, and misunderstanding of beneficiaries needs, change resistance, absence of skilled manpower required for application, the inability of universities to accommodate the growing numbers of students, the imbalance between quantitative growth of students number and education numbers, lack of appropriate coordination between education output, lack of financial resources, the rush to see the results and needs of development plans. Hamoud, 2010, Alkhatib and Alkhatib, 2016). In addition (Azab, 2011) added that organizational inertia and 
inadequacy for work needs, weak attention to research, lack of teamwork, effective communication and trust between the faculties and departments, the existence of a conflict between stakeholders and the internal customers (students, teachers, administrators and staff) the main reasons.

TQM is the most important area of any organization as organizational development is directly related to the effective and successful implementation of TQM. But unfortunately, no adequate researches have been conducted about obstacles of application of TQM at higher education level. Therefore, the researchers will conduct the present study to identify obstacles of application TQM at SVU Institutions (Gharakhani et, al., 2013).

\section{Significance of the study}

The TQM in higher education at SVU institutions has little concern; efforts must be given to move directly toward TQM in higher education to deal with the new trend. From researchers' long experience working in SVU, (TQM) in higher education are below the predictable standards. Upgrading and application the TQM in higher education is relevant to identify obstacles to TQM application, and no previously studies were done regarding TQM obstacles at SVU, so this will the motive to the researchers to conduct this study.

Ami of the study

This study aims to

Identify the obstacles faced by SVU institutions in application TQM from academic staff perspective.

\section{Research questions}

What are the obstacles of TQM application in higher education institutions at SVU?

\section{Materials \& Methods}

Study design: A descriptive explorative research design was used in this study to identify obstacles of TQM application in higher education institutions at SVU.

Setting: The study was conducted in Faculties of; Nursing, Engineering, Arts and Commerce at SVU. These faculties was choose through list all faculties in SVU that not get accreditation and did not apply for accreditation, divided faculties into two groups (theory and practical) and assigned a number to each faculty and two faculties from each group were randomly selected (Stratified Random Sample) (represent $25 \%$ from a total number of faculties) .

Subjects: A sample of academic staff (from instructor to professor $) \quad(\mathrm{N}=160)$ selected from above mentioned study settings based on equal method through lists of academic staff in every faculty, assigned number for each member and 40 member were selected from each Faculty randomly.
Data collection tools

The tool of the study consists of two parts.

Part one: the personal characteristics of study participants (Age, sex, marital status, years of experience and job title).

Part two: TQM obstacles questionnaire, it was developed by Krajewski, Ritzman and Malhotra, (2011) to identify obstacles of implementing TQM It contained of 51 items and ten sub categories obstacles; top management (5 items), students (5 items), academic staff (5 items), financial resources (5 items), educational technology (5 items), relation with society (5 items), scientific research (5 items), organizational culture (5 items) and curriculum (5 items)

In addition five items of (TQM) application in institutions and study participants will ask about their suggestions for application of (TQM) in SVU Institutions.

\section{Scoring system}

The responses were measured by likert scale with five points; disagree, strongly disagree, " Uncertain ", " agree " and " strongly agree ", scoring was accordingly from 1 to 5 for each item respectively. A score type is determined by calculating the average value of all responses for the items in the type. Each mean score is associated with each level of obstacles; a total of nine mean scores obtained are compared. The highest score on obstacles indicates the most often obstacles.

Validity and reliability of the study tools:

The content validity of the tool was assessed by seven experts from faculty of nursing representative (three professors, one assistant professor and three lecturers) in the field of education from administration and community departments at Assiut and Quena universities (face validity through a jury). Then it was translated into Arabic using the translate-re-translate process.

\section{Pilot study}

A pilot study was conducted on a sample of $10 \%$ of academic staff to test the clarity and applicability of the study tool as well as to estimate the time needed to answer it. It also helped to test the feasibility and suitability of the study settings. Data obtained from the pilot study were analyzed; no modifications were done so included from the number of study sample. The reliability of the study tool was assessed in a pilot study by evaluating their internal consistency using Cronbchs alpha was $(\alpha=0.896)$ for study tool, thus indicating a high degree of reliability.

\section{Data collection phase}

Data were collected from academic staff in the study setting at SVU. The questionnaire sheet was selfadministered filled; one of the researchers was presented all the time to clarify any item that needed 
interpretation to the participant. The self-administered questionnaire took about 20 minutes for each participant to be filled. The whole duration for data collection took about two months from August to September 2019.

\section{Ethical Consideration}

To carry out the study at the selecting settings an official permission obtained from the responsible authorities. The researchers meet with head of departments to explain the aim of the study to gain their approval, participation, as well as organizing and arranging the academic staff participation according to nature of work of each department. Then the researchers started by introducing themselves to each group of academic staff and explain the aims of the study and getting agreement of them to participate in the research and they were informed that their participation is voluntary on that they have the right to share or refuse to participate in the study at any time without giving any reason. In addition, confidentiality of gathered information and privacy of the participants will assure through coding of all data.

\section{Statistical Design}

Data were collected, and fed into computer for analysis and presentation. Date entry and data analysis were done using SPSS version 19 (Statistical Package for Social Science). Data were presented using descriptive statistics as number, percentage, mean, standard deviation. Spearman correlation was done to measure correlation between quantitative variables. P-value considered statistically significant when $\mathrm{P}<0.05$.

\section{Results}

Table (1): Distribution of the study sample personal characteristics $(\mathrm{No}=160)$.

\begin{tabular}{|c|c|c|}
\hline Items & No & $\%$ \\
\hline \multicolumn{3}{|l|}{ Age: (years) } \\
\hline $23-32$ & 109 & 68.2 \\
\hline $33-42$ & 33 & 20.6 \\
\hline $43-52$ & 13 & 8.1 \\
\hline $53-62$ & 5 & 3.1 \\
\hline Mean \pm SD (Range) & \multicolumn{2}{|c|}{$32.10 \pm 8.030(23-59)$} \\
\hline \multicolumn{3}{|l|}{ Sex: } \\
\hline Male & 73 & 45.6 \\
\hline Female & 87 & 54.4 \\
\hline \multicolumn{3}{|l|}{ Marital status: } \\
\hline Single & 68 & 42.5 \\
\hline Married & 89 & 55.6 \\
\hline Divorced & 3 & 1.9 \\
\hline Widow & 0 & \\
\hline \multicolumn{3}{|l|}{ Qualification: } \\
\hline Demonstrator & 52 & 32.5 \\
\hline Assistant lecture & 58 & 36.3 \\
\hline Lecture & 42 & 26.2 \\
\hline Assistant professor & 5 & 3.1 \\
\hline Professor & 3 & 1.9 \\
\hline \multicolumn{3}{|l|}{ Years of experience: } \\
\hline $1-10$ & 130 & 81.2 \\
\hline $11-20$ & 22 & 13.8 \\
\hline $21-30$ & 5 & 3.1 \\
\hline $31-40$ & 3 & 1.9 \\
\hline
\end{tabular}


Table (2): Obstacles of TQM application in higher education institutions at SVU (No=160).

\begin{tabular}{|c|c|c|c|c|c|c|c|c|c|c|}
\hline \multirow[t]{2}{*}{ Items } & \multicolumn{2}{|c|}{$\begin{array}{l}\text { Strongly } \\
\text { disagree }\end{array}$} & \multicolumn{2}{|c|}{ disagree } & \multicolumn{2}{|c|}{ Uncertain } & \multicolumn{2}{|c|}{ Agree } & \multicolumn{2}{|c|}{$\begin{array}{c}\text { Strongly } \\
\text { agree }\end{array}$} \\
\hline & No. & $\%$ & No. & $\%$ & No. & $\%$ & No & $\%$ & No. & $\%$ \\
\hline \multicolumn{11}{|l|}{ - Top management obstacles } \\
\hline $\begin{array}{l}\text { 1. Weak human relations between top management } \\
\text { and employees. }\end{array}$ & 8 & 5 & 25 & 15.6 & 30 & 18.8 & 48 & 30 & 49 & 30.6 \\
\hline $\begin{array}{l}\text { 2. Top management is not satisfied with the } \\
\text { application of total quality management. }\end{array}$ & 22 & 13.8 & 54 & 33.8 & 27 & 16.9 & 30 & 18.8 & 27 & 16.9 \\
\hline $\begin{array}{l}\text { 3. Lack of understanding by top management of } \\
\text { the needs of employees. }\end{array}$ & 6 & 3.8 & 18 & 11.2 & 28 & 17.5 & 61 & 38.1 & 47 & 29.4 \\
\hline $\begin{array}{|llll|}\text { 4. Top management neglects complaints and } \\
\text { suggestions }\end{array}$ & 6 & 3.8 & 35 & 21.9 & 39 & 24.4 & 39 & 24.4 & 41 & 25.6 \\
\hline $\begin{array}{l}\text { 5. The administration is not interested in training } \\
\text { staff to solve problems. }\end{array}$ & 3 & 1.9 & 25 & 15.6 & 28 & 17.5 & 61 & 38.1 & 43 & 26.9 \\
\hline \multicolumn{11}{|l|}{ - Students obstacles } \\
\hline 1. The large number of students in the classroom. & 3 & 1.9 & 13 & 8.1 & 14 & 8.8 & 39 & 24.4 & 91 & 56.9 \\
\hline 2. High repetition rates among students. & 14 & 8.8 & 57 & 35.6 & 32 & 20 & 34 & 21.2 & 23 & 14.4 \\
\hline 3. Poor student interaction within the classroom. & 8 & 5 & 29 & 18.1 & 33 & 20.6 & 53 & 33.1 & 37 & 23.1 \\
\hline 4. Reduced student motivation to learn. & 7 & 4.4 & 18 & 11.2 & 23 & 14.4 & 55 & 34.4 & 57 & 35.6 \\
\hline $\begin{array}{l}\text { 5. Poor students' understanding of the concept of } \\
\text { quality is the responsibility of all. }\end{array}$ & 3 & 1.9 & 4 & 2.5 & 19 & 11.9 & 60 & 37.5 & 74 & 46.2 \\
\hline \multicolumn{11}{|l|}{ - Human resources obstacles } \\
\hline $\begin{array}{l}\text { 1. Imbalance between staff members and student } \\
\text { numbers. }\end{array}$ & 3 & 1.9 & 8 & 5 & 14 & 8.8 & 39 & 24.4 & 96 & 60 \\
\hline $\begin{array}{l}\text { 2. The use of traditional teaching methods by staff } \\
\text { members. }\end{array}$ & 2 & 1.2 & 18 & 11.2 & 30 & 18.8 & 65 & 40.6 & 45 & 28.1 \\
\hline $\begin{array}{l}\text { 3. Lack of adequate knowledge of TQM by staff } \\
\text { members. }\end{array}$ & 3 & 1.9 & 15 & 9.4 & 28 & 17.5 & 62 & 38.8 & 52 & 32.5 \\
\hline $\begin{array}{l}\text { 4. Lack of trust and cooperation among staff } \\
\text { members. }\end{array}$ & 8 & 5 & 16 & 10 & 37 & 23.1 & 47 & 29.4 & 52 & 32.5 \\
\hline $\begin{array}{l}\text { 5. Scarcity of qualified staff members working } \\
\text { faculty. }\end{array}$ & 9 & 5.6 & 31 & 19.4 & 24 & 15 & 43 & 26.9 & 53 & 33.1 \\
\hline \multicolumn{11}{|l|}{ - Financial resources obstacles } \\
\hline $\begin{array}{l}\text { 1. Lack of financial resources available to the } \\
\text { faculty. }\end{array}$ & 3 & 1.9 & 9 & 5.6 & 16 & 10 & 39 & 24.4 & 93 & 58.1 \\
\hline $\begin{array}{l}\text { 2. The faculty does not rely on various sources of } \\
\text { funding. }\end{array}$ & 1 & .6 & 13 & 8.1 & 25 & 15.6 & 60 & 37.5 & 61 & 38.1 \\
\hline $\begin{array}{l}\text { 3. Lack of participation of workers in funding the } \\
\text { faculty. }\end{array}$ & 11 & 6.9 & 17 & 10.6 & 29 & 18.1 & 52 & 32.5 & 51 & 31.9 \\
\hline $\begin{array}{l}\text { 4. The lack of a specialized advisory office that } \\
\text { supports the funding of the faculty }\end{array}$ & 5 & 3.1 & 14 & 8.8 & 30 & 18.8 & 33 & 20.6 & 78 & 48.8 \\
\hline $\begin{array}{l}\begin{array}{l}\text { 5. Lack of financial specialties to motivate } \\
\text { employee. }\end{array} \\
\end{array}$ & 2 & 1.2 & 8 & 5 & 16 & 10 & 42 & 26.2 & 92 & $\mathbf{5 7 . 5}$ \\
\hline \multicolumn{11}{|l|}{\begin{tabular}{|l|l|} 
Educational technology obstacles \\
\end{tabular}} \\
\hline $\begin{array}{l}\text { 1. Failure to provide laboratories with sufficient } \\
\text { tools to benefit academic programs. }\end{array}$ & 5 & 3.1 & 12 & 7.5 & 24 & 15 & 56 & 35 & 63 & 39.4 \\
\hline $\begin{array}{l}\text { 2. Failure to provide classrooms to implement } \\
\text { necessary academic programs. }\end{array}$ & 2 & 1.2 & 8 & 5 & 26 & 16.2 & 61 & 38.1 & 63 & 39.4 \\
\hline $\begin{array}{l}\text { 3. Weak educational materials needed for the } \\
\text { academic programs offered. }\end{array}$ & 3 & 1.9 & 15 & 9.4 & 30 & 18.8 & 50 & 31.2 & 62 & 38.8 \\
\hline $\begin{array}{l}\text { 4. Lack of electronic libraries and information } \\
\text { search system. }\end{array}$ & 17 & 10.6 & 22 & 13.8 & 28 & 17.5 & 49 & 30.6 & 44 & 27.5 \\
\hline $\begin{array}{l}\text { 5. Dependence on traditional teaching methods and } \\
\text { the lack of newer ones. }\end{array}$ & 1 & .6 & 25 & 15.6 & 26 & 16.2 & 57 & 35.6 & 51 & 31.9 \\
\hline
\end{tabular}




\begin{tabular}{|c|c|c|c|c|c|c|c|c|c|c|}
\hline \multirow[t]{2}{*}{ Items } & \multicolumn{2}{|c|}{$\begin{array}{l}\text { Strongly } \\
\text { disagree }\end{array}$} & \multicolumn{2}{|c|}{ disagree } & \multicolumn{2}{|c|}{ Uncertain } & \multicolumn{2}{|c|}{ Agree } & \multicolumn{2}{|c|}{$\begin{array}{l}\text { Strongly } \\
\text { agree }\end{array}$} \\
\hline & No. & $\%$ & No. & $\%$ & No. & $\%$ & No & $\%$ & No. & $\%$ \\
\hline \multicolumn{11}{|l|}{ - Community service obstacles } \\
\hline $\begin{array}{l}\text { 1. Lack of joining faculty programs with } \\
\text { development plans in the community }\end{array}$ & 8 & 5 & 8 & 5 & 32 & 20 & 54 & 33.8 & 58 & 36.2 \\
\hline $\begin{array}{l}\text { 2. Lack of interest in the faculty to find jobs for its } \\
\text { graduates }\end{array}$ & 13 & 8.1 & 14 & 8.8 & 21 & 13.1 & 47 & 29.4 & 65 & 40.6 \\
\hline $\begin{array}{l}\text { 3. Weak participation of the private sector in the } \\
\text { faculty programs }\end{array}$ & 6 & 3.8 & 12 & 7.5 & 23 & 14.4 & 49 & 30.6 & 70 & 43.8 \\
\hline $\begin{array}{l}\text { 4. Lack of contribution of the faculty in solving } \\
\text { realistic problems in society }\end{array}$ & 7 & 4.4 & 12 & 7.5 & 28 & 17.5 & 63 & 39.4 & 50 & 31.2 \\
\hline $\begin{array}{l}\text { 5. Lack of participation of faculty professors in } \\
\text { seminars and conferences }\end{array}$ & 13 & 8.1 & 20 & 12.5 & 46 & 28.8 & 44 & 27.5 & 37 & 23.1 \\
\hline \multicolumn{11}{|l|}{ - Obstacles to scientific research } \\
\hline $\begin{array}{l}\text { 1. Scientific research does not emphasis on } \\
\text { contemporary topics }\end{array}$ & 14 & 8.8 & 27 & 16.9 & 32 & 20 & 52 & 32.5 & 35 & 21.9 \\
\hline $\begin{array}{l}\text { 2. Lack of moral incentives provided to enrich } \\
\text { scientific research }\end{array}$ & 3 & 1.9 & 5 & 3.1 & 26 & 16.2 & 63 & 39.4 & 63 & 39.4 \\
\hline $\begin{array}{l}\text { 3. Lack of financial budget allocated for scientific } \\
\text { research within the budget of the faculty }\end{array}$ & 4 & 2.5 & 4 & 2.5 & 28 & 17.5 & 51 & 31.9 & 73 & 45.6 \\
\hline $\begin{array}{l}\text { 4. Lack of publications of refereed scientific } \\
\text { journals }\end{array}$ & 4 & 2.5 & 14 & 8.8 & 31 & 19.4 & 51 & 31.9 & 60 & $\mathbf{3 7 . 5}$ \\
\hline $\begin{array}{l}\text { 5. Weak cooperation between faculty and } \\
\text { government institutions }\end{array}$ & 3 & 1.9 & 4 & 2.5 & 36 & 22.5 & 58 & 36.2 & 59 & 36.9 \\
\hline \multicolumn{11}{|l|}{ - Organizational culture obstacles } \\
\hline $\begin{array}{l}\text { 1. Negative organizational climate for the culture } \\
\text { of TQM }\end{array}$ & 2 & 1.2 & 8 & 5 & 30 & 18.8 & 71 & 44.4 & 49 & 30.6 \\
\hline $\begin{array}{l}\text { 2. Misunderstanding of the human aspects of the } \\
\text { employee }\end{array}$ & 2 & 1.2 & 8 & 5 & 30 & 18.8 & 61 & 38.1 & 59 & 36.9 \\
\hline $\begin{array}{l}\text { 3. Weakness of the university's readiness to change } \\
\text { its culture to suit the requirements of TQM }\end{array}$ & 2 & 1.2 & 15 & 9.4 & 45 & 28.1 & 58 & 36.2 & 40 & 25 \\
\hline $\begin{array}{l}\text { 4. Low constructive dialogue with staff to educate } \\
\text { them on TQM principles }\end{array}$ & 1 & 6 & 11 & 6.9 & 29 & 18.1 & 70 & 43.8 & 49 & 30.6 \\
\hline $\begin{array}{l}\text { 5. Lack of clarification of quality culture among } \\
\text { employee }\end{array}$ & 1 & 6 & 9 & 5.6 & 25 & 15.6 & 71 & 44.4 & 54 & 33.8 \\
\hline \multicolumn{11}{|l|}{ - Educational curriculum obstacles } \\
\hline $\begin{array}{l}\text { 1. Low capacity of educational curricula to } \\
\text { accommodate the variables of the age }\end{array}$ & 5 & 3.1 & 18 & 11.2 & 36 & 22.5 & 49 & 30.6 & 52 & 32.5 \\
\hline $\begin{array}{l}\text { 2. Inadequate educational curricula for the labor } \\
\text { market }\end{array}$ & 9 & 5.6 & 17 & 10.6 & 33 & 20.6 & 52 & 32.5 & 49 & 30.6 \\
\hline $\begin{array}{l}\text { 3. The inability of the educational curricula to } \\
\text { equip the student with problem solving skills }\end{array}$ & 8 & 5 & 24 & 15 & 33 & 20.6 & 51 & 31.9 & 44 & 27.5 \\
\hline $\begin{array}{l}\text { 4. Weak educational curricula 'ability to establish } \\
\text { high values }\end{array}$ & 7 & 4.4 & 21 & 13.1 & 47 & 29.4 & 46 & 28.8 & 39 & 24.4 \\
\hline $\begin{array}{l}\text { 5. The curriculum does not fulfill the student's } \\
\text { wishes and tendencies. }\end{array}$ & 6 & 3.8 & 22 & 13.8 & 45 & 28.1 & 48 & 30 & 39 & 24.4 \\
\hline
\end{tabular}


Table (3): The suggestions for application of (TQM) in SVU Institutions. (No= 160).

\begin{tabular}{|c|c|c|c|c|c|c|c|c|c|c|}
\hline \multirow[t]{2}{*}{ Items } & \multicolumn{2}{|c|}{$\begin{array}{l}\text { Strongly } \\
\text { disagree }\end{array}$} & \multicolumn{2}{|c|}{ Disagree } & \multicolumn{2}{|c|}{ Uncertain } & \multicolumn{2}{|c|}{ Agree } & \multicolumn{2}{|c|}{$\begin{array}{l}\text { Strongly } \\
\text { agree }\end{array}$} \\
\hline & No. & $\%$ & No. & $\%$ & No. & $\%$ & No & $\%$ & No & $\%$ \\
\hline $\begin{array}{l}\text { 1. The faculty does not rely on strategic planning } \\
\text { to achieve educational goals }\end{array}$ & 8 & 5 & 16 & 10 & 44 & $\begin{array}{c}27 . \\
5\end{array}$ & 47 & 29.4 & 45 & 28.1 \\
\hline 2. The deanship does not support TQM activities & 14 & 8.8 & 38 & 23.8 & 45 & $\begin{array}{c}28 . \\
1\end{array}$ & 35 & 21.9 & 28 & 17.5 \\
\hline $\begin{array}{l}\text { 3. The deanship of the college is little concerned } \\
\text { with meeting the needs and desires of students, } \\
\text { their families and society }\end{array}$ & 8 & 5 & 29 & 18.1 & 51 & $\begin{array}{c}31 . \\
9\end{array}$ & 43 & 26.9 & 29 & 18.1 \\
\hline $\begin{array}{l}\text { 4. The faculty does not practice continuous } \\
\text { improvement activities to raise the efficiency } \\
\text { of performance }\end{array}$ & 8 & 5 & 20 & 12.5 & 48 & 30 & 57 & 35.6 & 27 & 16.9 \\
\hline $\begin{array}{l}\text { 5. The faculty rarely commends its staff in } \\
\text { specialized quality training courses }\end{array}$ & 19 & $\begin{array}{c}11 . \\
9\end{array}$ & 27 & 16.9 & 30 & $\begin{array}{c}18 . \\
8\end{array}$ & 46 & 28.8 & 38 & 23.8 \\
\hline Mean \pm SD & & & & & & & & & & \\
\hline
\end{tabular}

Table (4): Mean score regarding Obstacles of TQM Application (No=160)

\begin{tabular}{|l|c|}
\hline \multicolumn{1}{|c|}{ Items } & Mean \pm SD \\
\hline Top management obstacles & $\mathbf{1 7 . 5 4 \pm \mathbf { 4 . 7 1 3 }}$ \\
\hline Students obstacles & $18.84 \pm 3.788$ \\
\hline Human resources obstacles & $19.46 \pm 3.743$ \\
\hline Financial resources obstacles & $\mathbf{2 0 . 4 4 \pm 3 . 7 5 3}$ \\
\hline Educational technology obstacles & $19.39 \pm 4.165$ \\
\hline Community service obstacles & $19.11 \pm 4.307$ \\
\hline Obstacles to scientific research & $19.68 \pm 3.680$ \\
\hline Organizational culture obstacles & $19.72 \pm 3.599$ \\
\hline Educational curriculum obstacles & $18.25 \pm 4.919$ \\
\hline Total obstacles of TQM (Mean $\mathbf{E}$ SD) & $172 \pm 36.667$ \\
\hline
\end{tabular}

Table (5): The relationship between obstacles of TQM application and age of studied sample $\mathrm{N}=(\mathbf{1 6 0})$

\begin{tabular}{|l|c|c|c|c|c|}
\hline \multirow{2}{*}{\multicolumn{2}{|c|}{ Items }} & \multicolumn{3}{c|}{ Age (years) } & \multirow{2}{*}{$\begin{array}{c}\text { P- } \\
\text { value }\end{array}$} \\
\cline { 2 - 6 } & $\mathbf{2 3 - 3 2}$ & $\mathbf{3 3 - 4 2}$ & $\mathbf{4 3 - 5 2}$ & $53-62$ \\
\cline { 2 - 6 } & Mean \pm SD & Mean \pm SD & Mean \pm SD & Mean \pm SD & \\
\hline - Top management obstacles & $17.61 \pm 5.037$ & $18.12 \pm 3.629$ & $16.38 \pm 4.464$ & $15.20 \pm 4.324$ & 0.472 \\
\hline - Students obstacles & $19.09 \pm 3.994$ & $18.70 \pm 3.661$ & $16.85 \pm 2.267$ & $19.40 \pm 1.342$ & 0.238 \\
\hline - Human resources obstacles & $19.34 \pm 4.144$ & $20.30 \pm 2.518$ & $19.08 \pm 2.499$ & $17.60 \pm 3.578$ & 0.371 \\
\hline - Financial resources obstacles & $20.37 \pm 3.953$ & $20.88 \pm 3.533$ & $20.00 \pm 3.317$ & $20.40 \pm 1.673$ & 0.882 \\
\hline - Educational technology obstacles & $19.70 \pm 4.122$ & $18.70 \pm 4.599$ & $18.23 \pm 3.811$ & $20.20 \pm 2.490$ & 0.443 \\
\hline - Community service obstacles & $19.36 \pm 4.065$ & $18.76 \pm 5.339$ & $17.85 \pm 3.870$ & $19.20 \pm 3.194$ & 0.640 \\
\hline - Obstacles to scientific research & $19.83 \pm 3.574$ & $19.52 \pm 4.317$ & $18.54 \pm 3.230$ & $20.60 \pm 2.608$ & 0.619 \\
\hline - Organizational culture obstacles & $19.39 \pm 3.488$ & $21.76 \pm 2.622$ & $18.00 \pm 4.916$ & $18.20 \pm 3.033$ & $\mathbf{0 . 0 0 1 *}$ \\
\hline - Educational Curriculum obstacles & $18.70 \pm 4.578$ & $18.42 \pm 5.327$ & $14.54 \pm 5.868$ & $17.00 \pm 3.674$ & $\mathbf{0 . 0 3 3 *}$ \\
\hline
\end{tabular}

(*) Significant at $P \leq 0.05$ 
Table (6): The relationship between obstacles of TQM application and Sex of Studied Sample N=(160)

\begin{tabular}{|l|c|c|c|}
\hline \multirow{2}{*}{\multicolumn{1}{|c|}{ Items }} & \multicolumn{2}{|c|}{ Sex } & \multirow{2}{*}{ P-value } \\
\cline { 2 - 3 } & Male & Female & \\
\cline { 2 - 3 } & Mean \pm SD & Mean \pm SD & 0.230 \\
\hline - Top management obstacles & $18.03 \pm 4.595$ & $17.13 \pm 4.798$ & 0.183 \\
\hline - Students obstacles & $19.27 \pm 3.878$ & $18.47 \pm 3.694$ & 0.680 \\
\hline - Human resources obstacles & $19.33 \pm 3.358$ & $19.57 \pm 4.054$ & 0.749 \\
\hline - Financial resources obstacles & $20.55 \pm 3.416$ & $20.36 \pm 4.032$ & $\mathbf{0 . 0 5 8}$ \\
\hline - Educational technology obstacles & $20.07 \pm 3.653$ & $18.82 \pm 4.492$ & $\mathbf{0 . 0 0 4}^{*}$ \\
\hline - Community service obstacles & $20.16 \pm 3.375$ & $18.22 \pm 4.797$ & 0.090 \\
\hline - Obstacles to scientific research & $20.22 \pm 3.396$ & $19.23 \pm 3.863$ & $\mathbf{0 . 0 1 9}^{*}$ \\
\hline - Organizational culture obstacles & $20.45 \pm 3.197$ & $19.11 \pm 3.817$ & $\mathbf{0 . 0 3 6}^{*}$ \\
\hline - Educational curriculum obstacles & $19.14 \pm 4.331$ & $17.51 \pm 5.274$ & \\
\hline
\end{tabular}

* Significant at $P \leq 0.05$

Table (7): The relationship between obstacles to TQM application and marital status $N=(160)$

\begin{tabular}{|l|c|c|c|c|}
\hline \multirow{2}{*}{\multicolumn{1}{|c|}{ Items }} & \multicolumn{3}{|c|}{ Marital status } & \multirow{2}{*}{ P-value } \\
\cline { 2 - 5 } & Single & Married & Divorced & \\
\cline { 2 - 5 } & Mean \pm SD & Mean \pm SD & Mean \pm SD & \\
\hline - Top management obstacles & $17.35 \pm 5.136$ & $17.60 \pm 4.402$ & $20.00 \pm 4.359$ & 0.629 \\
\hline - Students obstacles & $19.18 \pm 3.644$ & $18.58 \pm 3.896$ & $18.67 \pm 4.619$ & 0.625 \\
\hline - Human resources obstacles & $18.82 \pm 4.143$ & $19.87 \pm 3.385$ & $22.00 \pm 2.000$ & 0.111 \\
\hline - Financial resources obstacles & $20.65 \pm 3.536$ & $20.40 \pm 3.857$ & $17.00 \pm 5.196$ & 0.256 \\
\hline - Educational technology obstacles & $19.87 \pm 3.928$ & $19.02 \pm 4.216$ & $19.33 \pm 8.145$ & 0.455 \\
\hline - Community service obstacles & $18.99 \pm 4.148$ & $19.15 \pm 4.484$ & $20.67 \pm 3.055$ & 0.799 \\
\hline - Obstacles to scientific research & $19.56 \pm 3.307$ & $19.74 \pm 3.941$ & $20.67 \pm 4.933$ & 0.856 \\
\hline - Organizational culture obstacles & $19.01 \pm 3.235$ & $20.24 \pm 3.829$ & $20.67 \pm 2.082$ & 0.097 \\
\hline
\end{tabular}

* Significant at $P \leq 0.05$

Table (8): The Relationship between Obstacles of TQM Application and Years of experience N= (160).

\begin{tabular}{|l|c|c|c|c|c|}
\hline \multirow{2}{*}{\multicolumn{1}{|c|}{ Items }} & \multicolumn{4}{c|}{ Years of experience } & \multirow{2}{*}{$\begin{array}{c}\text { P- } \\
\text { value }\end{array}$} \\
\cline { 2 - 5 } & $\mathbf{1 - 1 0}$ & $\mathbf{1 1 - 2 0}$ & $\mathbf{2 1 - 3 0}$ & $\mathbf{3 1 - 4 0}$ & \\
\cline { 2 - 5 } & Mean \pm SD & Mean \pm SD & Mean \pm SD & Mean \pm SD & \\
\hline - Top management obstacles & $17.71 \pm 4.817$ & $17.14 \pm 4.507$ & $15.60 \pm 2.302$ & $16.33 \pm 5.508$ & 0.716 \\
\hline - Students obstacles & $18.99 \pm 3.814$ & $18.00 \pm 4.152$ & $18.20 \pm 2.168$ & $19.33 \pm 1.155$ & $\mathbf{0 . 6 8 9}$ \\
\hline - Human resources obstacles & $19.46 \pm 3.902$ & $20.00 \pm 2.845$ & $19.20 \pm 2.588$ & $16.00 \pm 3.464$ & $\mathbf{0 . 3 8 8}$ \\
\hline - Financial resources obstacles & $20.35 \pm 3.921$ & $20.64 \pm 3.155$ & $21.80 \pm 2.864$ & $20.67 \pm 1.155$ & $\mathbf{0 . 8 5 3}$ \\
\hline - Educational technology obstacles & $19.43 \pm 4.198$ & $18.77 \pm 4.309$ & $21.20 \pm 3.962$ & $19.00 \pm 1.732$ & $\mathbf{0 . 6 9 4}$ \\
\hline - Community service obstacles & $18.95 \pm 4.505$ & $19.82 \pm 3.202$ & $21.00 \pm 4.062$ & $17.67 \pm 2.309$ & $\mathbf{0 . 5 5 9}$ \\
\hline - Obstacles to scientific research & $19.61 \pm 3.759$ & $20.00 \pm 3.703$ & $20.40 \pm 2.881$ & $19.33 \pm 1.155$ & $\mathbf{0 . 9 3 4}$ \\
\hline - Organizational culture obstacles & $19.69 \pm 3.368$ & $20.14 \pm 5.017$ & $20.00 \pm 2.121$ & $17.67 \pm 4.041$ & $\mathbf{0 . 7 3 1}$ \\
\hline
\end{tabular}

(*) Significant at $P \leq 0.05$ 
Table (9): Comparison of mean and standard deviation for the obstacles and application of TQM as perceived by participants by setting $N=(160)$.

\begin{tabular}{|c|c|c|c|c|c|}
\hline \multirow{3}{*}{ Items } & \multicolumn{4}{|c|}{ Faculties } & \multirow{3}{*}{$\begin{array}{c}P- \\
\text { value }\end{array}$} \\
\hline & Nursing & Engineering & Art & Commerce & \\
\hline & Mean \pm SD & Mean \pm SD & Mean \pm SD & Mean \pm SD & \\
\hline - Top management obstacles & $17.40 \pm 4.284$ & $19.32 \pm 5.544$ & $15.68 \pm 4.022$ & $17.75 \pm 4.289$ & 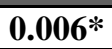 \\
\hline - Students obstacles & $17.82 \pm 3.441$ & $20.25 \pm 4.156$ & $18.20 \pm 3.495$ & $19.08 \pm 3.689$ & 0.020* \\
\hline - Human resources obstacles & $20.12 \pm 3.337$ & $20.20 \pm 3.844$ & $18.15 \pm 4.538$ & $19.38 \pm 2.798$ & 0.050* \\
\hline - Financial resources obstacles & $21.02 \pm 3.977$ & $20.42 \pm 3.713$ & $19.62 \pm 4.235$ & $20.70 \pm 2.963$ & 0.387 \\
\hline - Educational technology obstacle & $17.60 \pm 4.355$ & $20.20 \pm 4.586$ & $19.42 \pm 4.082$ & $20.32 \pm 3.033$ & 0.011* \\
\hline - Community service obstacles & $16.28 \pm 5.174$ & $19.65 \pm 4.042$ & $19.60 \pm 3.636$ & $20.90 \pm 2.687$ & 0.000* \\
\hline - Obstacles to scientific research & $18.72 \pm 2.944$ & $20.62 \pm 4.527$ & $19.22 \pm 3.833$ & $20.15 \pm 3.009$ & $0.085 *$ \\
\hline - Organizational culture obstacles & $19.12 \pm 3.090$ & $19.85 \pm 4.383$ & $18.62 \pm 3.564$ & $21.30 \pm 2.681$ & $0.005 *$ \\
\hline - Educational Curriculum obstacle & $14.95 \pm 4.472$ & $19.50 \pm 5.033$ & $18.60 \pm 4.272$ & $19.95 \pm 4.385$ & $0.000^{*}$ \\
\hline - Application of TQM & $15.90 \pm 3.901$ & $18.18 \pm 5.887$ & $16.02 \pm 4.622$ & $17.85 \pm 4.447$ & $0.062 *$ \\
\hline
\end{tabular}

Statistical significant difference $(P \leq 0.05)$

Table (1): Shows distribution of the study sample personal characteristics. The data in this table revealed that the academic staff were $\mathbf{1 6 0}$, the highest percent of them $(\mathbf{8 1 . 2 \%})$ had from 1 to 10 years of experience, about (68. 2\%) of them had their age from 23 to 32 years, slightly more than half of them $\mathbf{( 5 5 . 6 \% )}$ were married,. and about (54.4) of them were females. It was observed, that about $\mathbf{( 3 6 . 3 \% )}$ of them were assistant lecture.

Table (2): Reveals obstacles of TQM application in higher education institutions at SVU. The data in this table demonstrated that as regard to top management obstacles, about (38.1\%) agreed that lack of understanding by top management of the needs of employee and the administration is not interested in training staff to solve problems and about (30.6\%) strongly agreed that weak human relations between top management and employees. As regard to students obstacles, slightly more than half of them $(56.9 \%)$ strongly agreed that the large number of students in the classroom and about (46.2\%) of them strongly agreed that poor students' understanding that the concept of quality is the responsibility of all. In relation to human resources obstacles, about $(60 \%)$ strongly agreed that imbalance between staff members and student numbers. As regard to obstacles to scientific research, about (45.6\%) strongly agreed lack of financial budget allocated for scientific research within the budget of the faculty and about $(\mathbf{3 7 . 5} \%)$ strongly agreed lack of publications of refereed scientific journals In relation to financial resources obstacles about $\mathbf{5 8 . 1 \%}$ ) of them strongly agreed that lack of financial resources available to the faculty and about $(\mathbf{5 7 . 5 \%})$ of them agreed that lack of financial specialties to motivate employee. The data in this table also demonstrated that about (39.4\%) of participants perceived that among educational technology obstacles, failure to provide laboratories with sufficient tools to benefit academic programs and failure to provide classrooms to implement necessary academic programs. As regard to community service obstacles participant strongly agreed that lack of interest in the employee to find jobs for its graduates and weak participation of the private sector in the faculty programs $\mathbf{( 4 0 . 6 \% )}$ and $\mathbf{( 4 3 . 8 \% )}$ respectively.

With regard to organizational culture obstacles about $\mathbf{( 4 4 . 4 \% )}$ of participants agreed that there were negative organizational climate for the culture of TQM and lack of clarification of quality culture among employee and about (36.9\%) of them misunderstanding of the human aspects of the employee and $(\mathbf{3 3 . 8} \%)$ of them agreed that there were lack of clarification of quality culture among employee. The data in table also illustrated that about $\mathbf{3 2 . 5} \%$ ) of participants agreed that among educational curriculum obstacles, low capacity of educational curricula to accommodate the variables of the age and inadequate educational curricula for the labor market and inability of the educational curricula to equip the student with problem solving skills

Table (3): Shows the suggestions for application in SVU institutions. The data in this table demonstrated that about $\mathbf{2 9 . 4 \%}$ ) of academic staff agreed that faculty does not rely on strategic planning to achieve educational goals and about $\mathbf{2 9 . 4 \%}$ ) of them, agreed that the faculty does not practice continuous improvement activities to raise the efficiency of performance and about (28.8\%) of them agreed that the faculty rarely commends its staff in specialized quality training courses.

Table (4): Reveals mean scores and standard deviation of obstacles of TQ M. It was found that the high mean score was related to financial resources 
obstacles (20.44 \pm 3.753$)$, while low mean score $(\mathbf{1 7 . 5 4} \pm$ 4.713) was related to top management obstacles.

Table (5): Shows the relationship between obstacles of TQM application and age of studied sample. The data in table demonstrated that there were statistically significant differences between obstacles of the culture of the organization and educational curriculum and age with $(\mathbf{P}$-value $=0.001 *$ and $\mathbf{0 . 0 3 3} *$ ) respectively.

Table (6): Reveals the relationship between obstacles of TQM application and sex of studied sample. The data in this table demonstrated that there were statistically significant differences between obstacles of educational technology, educational curriculum, organizational culture and community service and sex with $(P$-value $=0.058 *, 0.036 *, 0.019 *$ and $0.004 *)$ respectively.

Table (7): Shows the relationship between obstacles of TQM application and marital status. The data in this table illustrated that there no statistically significant differences between obstacles of TQM application and marital status.

Table (8): Reveals the relationship between obstacles of TQM application and years of experience. The data in this table illustrated that there no statistically significant differences between obstacles. TQM application and years of experience.

Table (9): Displays comparison of mean and standard deviation for the obstacles and application of TQM as perceived by participants by setting. The data in this table demonstrated that, the highest mean and standard deviation were related to organizational culture obstacles in Faculty of Commerce Mean \pm SD $=21.30 \pm 2.681$ flowed by financial resources obstacles in Faculty of Nursing Mean \pm SD $=21.02 \pm 3.977$. It was observed that there were statistically significant differences between obstacles and application of TQM (top management, students, human resources, educational technology, community service, scientific research, culture of the organization, educational curriculum and applications of TQM $(* \mathbf{P} \leq \mathbf{0 . 0 0 6 *}, \mathbf{0 . 0 2 0 *}$, $0.050 *, 0.011 *, 0.000 *, 0.085 *, 0.005 * .0 .000 *$ and $\mathbf{0 . 0 6 2 *}$ ) respectively.

\section{Discussion}

Quality education is one of the fundamental building blocks of economic development. TQM has verified significant successes at the academic levels. It is has been applied widely in the higher education in the western hemisphere because it adopts advanced managerial methods to manage quality, and it seeks continuous improvements in the inputs, processes, and outputs. For these reasons and others, higher education institutions in SVU should pay attention to this philosophy and start to apply it gradually. The adoption of TQM shall assist higher education institutions in graduating human resources equipped with suitable knowledge and technology to participate in economic development in Egypt (Hassan, 2014).) This study was constructed as a descriptive explorative study in an attempt to identify obstacles of TQM applications in higher education institutions from academic staff perspective at SVU.

The finding of the present study pointed that the first top management obstacle to apply the TQM as perceived by academic staff were lack of understanding the needs of employees, the administration is not interested in training staff to solve problems and weak human relations between top management and employees (Table 2). This may attribute to that academics views variance about quality and the poor awareness among managers about importance of TQM, the prevalence of authoritarian management styles and traditional administrative methods in the management at SVU, In agreement with these study findings, Altartouri \& Joahat, (2016) indicated that obstacles of TQM application are: lack of leadership's commitment to implement TQM. In contrast Wani \& Mehraj, (2014) mentioned that successful implementation of TQM needs effective leadership, institutional commitment and a clear vision. Also, Phil, (2015) emphasized that to ensure successful implementation of TQM, top management must be totally involved in implementing and stimulating the TQM approach and explored that poor communication with employee is a challenge for the heads in implementing TQM.

According to Moreover Yusuf et al., (2015) effective leadership vital for successful implementation of TQM and stated that management leadership is a crucial factor in implementing TQM because it ensures well performance through influencing workforce within an organization.

As revealed by the study results, more than two third of academic staff agreed that students obstacles were large number of students in the classroom and students' don't understanding the concept of quality (Table 2). This due to absence of suitable climate of quality culture. This confirmed by Bin tareaf, (2013) \& Mozamel \& Abduwahld, (2015) which asserted that the higher education has witnessed a steady growth in students numbers in higher education institutions has not been accompanied by a analogous growth in buildings and equipment, devices and techniques, as well as the preparation and qualifications of faculty members and also in students services, which involve opposing consequences in terms of the quality of graduates 
Results of the study regarding to human resources obstacles showed that the majority of academic staff agreed that the most obstacles were imbalance between staff members and student numbers and lack of adequate knowledge of TQM by staff members (Table 2). This due to organizational inadequacy for work needs, and misunderstanding of beneficiaries needs. In the same line Alkhatib, \& Alkhatib, (2016) who stated that main obstacles of TQM application in education are: imbalance between quantitative growth of students number and education numbers, lack of appropriate coordination between education output and needs of development plans, and typical planning. Also these findings consistent with Mdouk (2016) who pointed that the major obstacles for successful implementation of TQM lack of knowledge about the self-assessment mechanisms, poor coordination between employees and departments and lack of interest in training.

As regard to financial resources obstacles the finding of the present study indicated that most of participants agreed that most obstacles were, lack of financial resources available to the faculties, absence of a specialized advisory office that supports the funding of the faculties and lack of financial specialties to motivate employee (Table 2). This may due to that SVU don't develop annual financial plan according to faculties needs, in agreement with this finding Ater, (2013) founded that financial resources are very beneficial in the process of TQM implementation. More over Phil, (2015) asserted that insufficient funding and resources was a main barrier in the way of effective implementation of TQM.

In relation to educational technology obstacles. results of this study revealed that slightly less than two third of participants agreed that most obstacles were failure to provide laboratories with sufficient tools to benefit academic programs and to provide classrooms to implement necessary academic programs and dependence on traditional teaching methods and the lack of newer ones (Table 2). This is in the same line with the study finding by Suleman, (2015) who explored that lack of infrastructural facilitates is one of the major challenges in TQM implementation.

In relation to community service obstacles, the study results declared that more than two third of academic staff agreed that most obstacles were lack of interest in the faculties to find jobs for its graduates and weak contribution of the private sector in the faculties programs (Table 2). The finding is congruence with Gharakhani, et al., (2013) which mentioned that community plays a remarkable role in uplifting and enriching institutional progress and is considered an influential and contributory factor towards the accomplishment of predetermined educational objectives therefore; the role of community cannot be ignored in implementing TQM.

Concerning to scientific research obstacles, the study results declared that most of participants agreed that most obstacles were lack of financial budget allocated for scientific research within the budget of the faculties and lack of moral incentives provided to enrich scientific research (Table 2). This result may be due to that the SVU is facing significant financial challenges of financial resources, lack external environmental changes affecting financial resources such as: increase number of students,

In the same context Karani, \& Okibo, (2012) which stated that personnel, educational materials and funding are very important for successful implementation of TQM, and mentioned that recognition, appreciation and rewarding activities may promote and stimulate workforce commitment for quality improvement. In addition, Hassan, \& Fan, (2016) concluded that training, tools and techniques that support the recognition and reward of desired behaviors and practices are essential to enable readiness for change and improve the level of readiness for TQM implementation

As regard to obstacles to the culture of the organization the present study showed that most of academic staff agreed that obstacles were negative organizational climate for the culture of TQM and lack of clarification of quality culture among employees (Table 2). This may be due to that faculties in SVU has many values, customs, norms and standards that may be a reason for change resistance, these finding in contrast with Alkraawi, (2016) who reported that effective implementation of TQM needs effective reforms in organizational environment and ensuring appropriate and supportive organizational culture and suitable climate of quality culture.

With regard to educational curriculum obstacles, study showed that the majority of academic staff agreed that obstacles were low capacity of educational curricula to accommodate the variables of the age and inadequate educational curricula for the labor market (Table 2). This may explained by the fact that academic staff don't care to link curriculum in SVU to labor market. In the same respect Al Naga \& Kamel, (2016) found that the highest obstacles for application TQM were curriculum.

The present study indicated that in relation to suggestions for TQM at SVU, about more than half of participants agreed that, the faculties does not rely on strategic planning to achieve educational goals and does not practice continuous improvement activities to raise the efficiency of performance and rarely commends its staff in specialized quality training courses (Table 3). This may explained by the fact that 
Faculties in SVU don't follow annual written training plan when select their staff for training and are selected them for training on the basis of favoritism and nepotism and the difference between quality policy and quality application system. In the same line Suleman, (2015) concluded that teachers are rarely given professional training and sometimes teachers are selected for professional training although they are not eligible for such training. In contrast this finding, Alnajjar \& Jawad (2014) who stated that the application of quality standards required of employees in educational institutions: High levels of professionalism, continuous training, better use of modern technology, and provision of leadership skills, reflected on the performance and work productivity and contribute to development in various dimensions.

Moreover, Yarahmadi \& Magd (2016) mentioned that Universities in general and Arab ones in particular are facing obstacles that may inhibit the effective application of quality, including: failure to provide incentives and financial rewards as well as estimates to support the efforts of quality, the lack of necessary training for workers in the field of quality, the lack of sufficient time to carry out quality, the lack of financial allocations sufficient to the quality, the low level of awareness about the quality, resisting change, poor support to senior leadership, and weak commitment to employees.

The finding of the present study revealed that, the high mean score in TQM application obstacles was financial resources obstacles (Table 4). In line with this study finding Kosgei,. (2014) who concluded that the important difficulties facing TQM application at universities are; lack of adequate budget and needed resources to ensure the success of application process. In contrast, Bassam \& Murad, (2016) which concluded that organizational culture obstacles occupies the first rank among application constraints in TQM application in universities.

It was found from the present study findings that there is a statistical significant difference between organization culture and educational curriculum obstacles and age (Tables 5). this may explained by the fact; students who had more years of experience were more willing to devote time in quality and carry on the value of quality which they learn during their undergraduate education, These finding consistent with Bassam \& Murad, (2016) who founded that there is no statistically significant effect of demographic factors (gender, age, experience, job title) to impediments of total quality management, Also there is a statistical significant difference between obstacles of educational technology, community service organization culture and educational curriculum and sex (Tables 6), incongruence with these present study finding, Faddaalah, (2009) concluded that there is no statistical significant difference of sex to obstacles of TQM application. Furthermore the present study illustrated that there were no statistically significant differences between obstacles of TQM application and marital status or years of experience (Tables 7\&8), in agreement with these finding, Mdouk, (2016) who founded that there is no difference in the averages of estimates of study sample perception toward obstacles of TQM application due to demographic variables.

Lastly, as depicted by the present study, there were statistically significant differences between obstacles of TQM application among academic staff in faculties of nursing, engineering, art and commerce, this may due those faculties in SVU has difference in the nature of education, rules, standards and regulation. In the same line Soomro \& Ahmad, (2012) who concluded that every institution approaches the quality from different cultural aspects, this means that we must pay attention to the factors that are important for successful implementation of quality management.

\section{Conclusion}

Based on the results of the present study, it can be concluded that

The results revealed that a number of obstacles were challenged SVU Faculties in implementing TQM, these obstacles were;

1. Financial resources,

2. Organization culture,

3. Scientific research,

4. Human resources,

5. Educational technology,

6. Community service,

7. Students,

8. Educational curriculum and

9. Top management.

The highest obstacles that limited TQM application in the SVU were financial resources obstacles followed by organizational culture obstacles.

\section{Recommendations}

Based on the findings of the present study, the researchers suggested the following recommendations:

1. Policy maker at SVU must use strategic long term planning, and effective policy for services quality and provide positive organizational climate for TQM application, and take care of the humanist aspects of the staff. 
2. Higher authority at SVU faculties must pay attention to the incentives (material and moral) of the faculty members, taking into account justice and touch priority opportunities to notify them of belonging and loyalty.

3. Adopt organizational development for studying prevailing organizational culture, and identify its components, choose leaders with administrative and academic experience to implement quality programs, changing the bureaucratic culture based on centralized power and organizational rigidity to quality culture and encouraging teamwork.

4. Encourage to the concept of quality in higher education institutions before adopting, formation of quality committees in all departments and develop guidelines and follow up work periodically.

5. Improve the level of scientific researches and the development of knowledge outside the framework of the promotion of science.

6. Provide training courses and workshops in the field of TQM application in higher education institutions and ongoing improvement and selfassessment. to ensure that there are efficient and effective work quality systems

7. Develop University working system to provide best services for students and society through computed services and speed up access to the concerned authorities, including students admission and registration

8. Provide supportive infrastructure for change and development of qualified human resources, material, technical infrastructures and renewable resources for education and learning that commensurate with the capacity of these institutions

9. Keeping up with the rapid changes in techniques and methods of teaching and the development of knowledge and skills with attention to quality in plan and to students 'opinions and suggestions to encourage freedom of expression and critical thinking

\section{References}

- Al Naga S., \& Kamel S., (2016): Obstacles to the Application of TQM in Higher Education, Journal of Al Alturas Faculty. Baghdad University. No 14. Pp.35-38

- Aladadi S., (2012): Obstacles to the Application of Total Quality in the Higher Education Institutions a Field Study. Arab Journal to Ensure the Quality of University Education. 9 (15), Pp. 66- 99, Riyadh, Saudi Arabia.

- Alkhatib A., \&Alkhatib R., (2016): TQM Educational Applications, the $8^{\text {th }}$ ed., Irbid, Jordan: the Modern Book World for Publication and Distribution.

- Alkraawi M., (2016): The Extent of Quality Management Application in University Education, a Comparison Study between the Civil Government Colleges and National Colleges from the Point of View of a Sample of Professors. Alqadisiya Journal of Administrative and Economic Sciences. No Vol.18, No. (1), Pp.85-109, the University of Qadisiyah, Iraq

- Alnajjar S., \& Jawad M., (2014): Study of Total Quality Obstacles Application in National University Education. Journal of Education and Training Studies, Vol. No. 3 (2), Pp. 51-60.

- Altartouri, M., \& Joahat A., (2016): TQM in Higher Education, Libraries and Information Centers Institutions. Jordan, Amman: Dar Almaserah for Publishing, Distribution and Printing.

- Ater, J., (2013): Challenges Facing the Implementation of TQM Practices in Public Secondary Schools in Kenya. Master Thesis, Administration Degree (Strategic Management Option) School of Business Kenyatta University.

- Azab M., (2011): Development of School Management in the Light of Total Quality Standards. Egypt, Alexandria, Modern University Office.

- Bassam A., \&. Murad A., (2016): Impediments of TQM Application at Higher Education Institutions, European Journal of Business and Management www.iiste.org ISSN 2222-1905 (Paper) ISSN 22222839 (Online) Vol. 8, No. Pp. 36, 2016.

- Bin Tareaf A., (2013): Scientific Research in Jordanian Higher Education In Situation: an Evaluation of the Status and Obesities Journal on Instructional Psychology Vol.36 No. (2) Pp.158168.

- Faddaalah M., (2009): The Extent of TQM in Nursing Colleges in Jordanian Universities, from the Stand Point of Administrators, Department Heads and Faculty Members. Unpublished MA Thesis, University of the Middle East Graduate Studies, Amman, Jordan.

- Gharakhani D., Rahmati, H., Farrokhi M., \& Farahmandian A., (2013): TQM and Organizational Performance. American Journal of Industrial Engineering, Vol.1 No. (3), Pp.46-50.

- Hammoud K., (2010): TQM and Customer Service. Amman, Jordan, Dar Almaserah for Publishing, Distribution and Printing.

- Hassan A., \& Fan S., (2016): Obstacles Hindering TQM Implementation in Secondary Schools in Saudi Arabia, School of Aerospace, Transport and Manufacturing, Cran field University (UK). 
- Hassan H., (2014): Obstacles to the Application of TQM at Parallel Master's Program in the Faculty of Social Sciences in Imam Muhammad Bin Saud Islamic University in Riyadh. Journal of Arabic Studies in Education and Psychology, Vol. 47 No. (3), Pp. 105- 144, Arab educators Association, Riyadh, Saudi Arabia.

- Jaafari M., (2011): Towards a Modern Arabic University: A New Era of Higher Education, the First Arab International Conference for Quality Assurance in Higher Education, University of Zarqa.

- Karani, S., \& Okibo, B., (2012): Effects of TQM Implementation on Business Performance In Service Institutions: A case of Kenya Wildlife Services. International Journal of Research Studies in Management, Vol.1 No. (1), Pp. 59-76

- Kosgei, M., (2014): Challenges Facing the Implementation of TQM in Secondary Schools: A Case of Eldoret East District, Kenya. Global Journal of Human Resource Management, Pp. 3, 12-18.

- Krajewski J., Ritzman P. and Malhotra Manoj K. (2011): Operations Management, Process and Value Chain, $9^{\text {th }}$ ed., Prentice-Hall, New Jersey.

- Mdouk N., (2016): Obstacles of TQM Application at Palestinian Universities in Gaza Governorates and Ways to overcome them. Unpublished MA Thesis, Islamic University, Gaza, Palestine

- Mozamel M., \& Abduwahld A., (2015): Challenges Facing Quality Application in Higher Education Institutions in Sudan. International Journal of Innovative Technology and Research. Volume 3, No.6, October - November 2015, Pp. 2488 - 2492/

- Papanthymou A., \& Papanthymou M., (2017): Quality Management in Higher Education: Review and Perspectives, Higher Education Studies; Vol. 7, No. 3; 2017. Published by Canadian Center of Science and Education.

- Phil S., (2015): Challenges to Successful TQM Implementation in Public Secondary Schools: A Case Study of Kohat District, Pakistan.

- Sahney S., Karunes S., \& Banwet D., (2011): TQM in Higher Education, the What and the Why?" Journal of Educational Planning and Administration, Vol. 15, No. (1), Pp.97-104.

- Soomro, T., \& Ahmad R., (2012): Quality in Higher Education: United Arab Emirates Perspective. Higher Education Studies, Vol. 2, No. (4), https://doi.org/10.5539/hes.v2n4p148.

- Suleman, Q., (2015): Managerial Challenges Faced by Fresh Directly Appointed Secondary School Heads in Kohat Division, Pakistan. Research on
Humanities and Social Sciences, Vol. 5, No. (5), Pp. 91-104.

- Wani I., Mehraj H., (2014): Total Quality Management in Education: An Analysis. International Journal of Humanities and Social Science Invention, 3 (6), 71-78

- Yadollah M., Massoud S., \& Oghaddam R., (2010): The Applicability of Quality Management Systems and Models to Higher Education: A new Perspective, The TQM Journal, Vol. 22, No. (2), Pp. 175 - 187.

- Yarahmadi F., \& Magd, H., (2016): Factors Affecting the Readiness of Higher Education Institutions' Environment for the Establishment of TQM in Oman. Paper Presented at the Twentieth International Conference on ISO and TQM, Oman. Abstract retrieved March 17, 2017, from http://www.hk5sa.com/icit/6.5 Oman-Farzaneh.pdf

- Yusuf Y., Gunasekaran A., \& Dan D., (2015): Implementation of TQM in China and Organization Performance: An Empirical Investigation. Total Quality Management \& Business Excellence. 